\title{
TÜRK VERGİ HUKUKU AÇISINDAN VAKIFLAR
}

Dr. Ahmet IȘERI

13.7.1967 tarih ve 903 sayılı Kanun ${ }^{1}$ ile yapılan değişiklikten önce de, vergi kanunlarımıda vakıflarla ilgili birçok hükümler mevcuttu. Bu kanun ile, vakıfları ve bunlarla ilgili işlemleri vergiden muaf tutan ve istisnalar getiren yeni hükümler konulduğu gibi, yürürlükte bulunan hükümlerden bir kısmı da değiștirilmiş bulunulmaktadır. Değişiklikten önceki ve sonraki bu hükümlerin tümünii, iç kategoride toplayabiliriz:

a) Vakıfları vergi mükellefi (vergi borçlusu) kılan hükümler,

b) Vakifları vergi borcundan muaf tutan ve istisnalar geti. ren hüikümler,

c) Vakıflara, tüzel kișiliği haiz olmaları dolayısiyle, vergilen. dirme ișlerinin yürütülmesi ile ilgili bir takım vecibeler yükleyen hükümler, başka bir deyimle, usul hukümleri.

\section{I - VAKIFLARI VERGİ MÜKELLEFI KILAN HÜKÜMLER}

Kurumlar Vergisi Kanununun 1 inci maddesinde, Kurumlar Vergisine tabi olan mükellefler ${ }^{2}$ saylırken, vakıflara ${ }^{3}$ ait iktisadî

\footnotetext{
1 Resmî Gazete, 24 Temmuz 1967, Sayı: 12655, s. 24. Bu Kanunun 6 nci mad. desinde öngörülen tiizü̧̈üun, Kanunun yürürlü̆ge girmesinden (24 Temmuz 1967) itibaren altı ay içersinde, yani 24 Ocak 1968'e kadar hazırlanması beJirtildiği halde, bu tüzüik, iki buçuk senelik bir geçikme ile, ancak 25.7.1970 tarihinde 7/1066 karar sayısı ve aTürk Medenî Kanunu Hüikümlerine Göre Kurulan Vakıflar Hakkında Tüzziikn adiyla yürürlüğe konulabilmiștir (Resmî Gazete, 21.8.1970, Sayı: 13586, s. 2-5).

Türk vakıflarının vergilendirilmesi konusunda, Alman vakıfları ile muka. yeseli bir etüd için bkz. Salih Şanver: Vakıfların Vergilendirilmesi, Eskișehir İktisadi ve Ticarî İlimler Akademisi Dergisi, C. IV, Haziran 1968. Sayı: 2, Ankara 1968, s. 1-13. Amerikan vakıflarının vergilendirilmesi konusunda bkz. Ahmet Isșeri : Amerikan Vakıflan Ũzerine Bir Inceleme, bu dergi, aşağıda s, 275 vd.

2213 sayıl Vergi Usul Kanununun verdiği tanıma göre «Mükellef, vergi kanunlarına göre, kendisine vergi borcu terettübeden gerçek veya tüzel kişidir».

${ }^{3}$ Maddede geçen "tesis» terimi, 903 sayılı Kanunun 3 üncü maddesi dikkate alınarak «vakıf» șeklinde değ̣iștirilmiş̧tir.
} 
işletmeler de zikredilmektedir (Kur. VK. 1/D). Bu hükme göre, bizatihi vakıflar değil, bunların iktisadî işletmeleri Kurumlar Ver. gisi mükellefi addedilmektedir.

Mükellefler hakkında tafsilâta giren kanunun sonraki madde. leri arasında, 5 inci maddede, vakıflara ait iktisadî ișletmeler şöyle izah edilmektedir : "... vakıf veya eski vakıflara ${ }^{4}$ ait veya bağlı olup 4 üncï maddede yazılı șartları haiz bulunan işletmeler ile ay. nı mahiyetteki işletmeler,... vakıf ve eski vakıfların iktisadî işletmeleridir».

4 ünciu maddeye yapılan atıf gereğince vakıflara (ve eski vakıflara) ait iktisadî işletmelerde aranacak şartlar şunlardır: Faaliyetleri devamlı olan ticarî, sınâ̂, ziraî işletmeler Kurumlar Vergisine tabi tutulacak; fakat bu işletmelerin vergi mükellefi olmaları için kazanç gayesi gütmek, tüzel kişiliğe sahip olmak, müstakil muhasebeleri ve kendilerine tahsis edilmiş vermayeleri bulunmak gibi şartlar aranmayacaktır .

Kur. VK. 5 'te görüldüğ̈ï üzere, aynı şartlar dahilinde yabancı vakıflara ait işletmeler de mükellef sayılmaktadır.

Kurumlar Vergisi ödeyecek olan bu iktisadî işletmeler (Türk, yabancI), Kur. VK'nun 9-12 nci maddelerine göre tam veya dar mükellef sayllırlar.

Bu kurumlarnn ödeyecekleri vergi nispeti \% 35 tir. Șayet iktisadî ișletme, sermaye șirketi șeklinde kurulmuş ise, Kur. VK. 1/A'. da sayılan mükellef grubuna (sermaye şirketleri) girecektir. Bu takdirde ödeyecekleri vergi nispeti \% $25^{\prime}$ tir. ${ }^{5}$

Kur. VK. 27'ye göre, vakıflara (ve eski vakıflara) ait iktisadî ișletmeler tüzel kișiliğe sahip değilseler, bu halde vergi vakıf (ve eski vakıf) namına tarh olunur.

\section{II - VAKIFLARI VERGI BORCUNDAN MUAF KILAN HÜ- KÜMLER}

A. Ge nel olarak:

Kur. VK'nun muafiyetlerle ilgili 7 nci maddesinin $7 \mathrm{nci}$ bentine göre, vakıflar (veya eski vakıflar) tarafından, ilim, fen ve giizel

4 Maddede geçen "vakuf"tan maksat, 5.6.1935 tarihli, 2762 sayll Vakıflar Kanuna tabi olan vakıflardır. Ancak, 903 sayılı Kanunun 3 üncü maddesi karșısında, «eski vakıf» șeklinde kullanılması zorunluluğu hasıl olmuştur.

${ }^{5}$ Sermaye şirketleri ile kooperatif șirketlerin vergi oran \% 20 iken, 27.3. 1969 tarih ve 1137 . saytl Kanun ile \% 25'e yükseltilmiștir. 
sanatlar ile tarım ve hayvancılığı öğretmek, yaymak, ıslah ve teşvik etmek maksadiyle işletilen müesseseler (okullar, okul atelyeleri, konservatuarlar, genel kütüphaneler, tiyatrolar, miizeler, sergiler, numune fidanlıkları, tohum ve hayvan sslâh ve üretim istasyonları, yarıs yerleri, kitap, gazete ve mecmua yayın evleri ve emsali müesseseler) (Kur. VK. 7/3) veya genel insan ve hayvan sağlığını koru. mak ve tedavi maksadiyle işletilen müesseseler (hastane, nekahethane, klinik, dispanser, prevantoryum, çocuk bakım evleri, hayvan hastaneleri ve dispanserleri, hayvan bakım evleri...) (Kur. VK. 7/4 veya içtimaî maksatlarla işletilen müesseseler (șefkat, rehin ve yar. dım sandiklar, fukara aşhaneleri, ...ögrenci yurtları ve pansiyon. Iarı gibi müiesseseler) (Kur. VK. 7/5) veya hükümetin yahut yetkili idare mercilerinin müsaadeleri ile açılan mahallî, millî veya millet. lerarası mahiyetteki sergiler, fuarlar, panayırlar (Kur. VK. 7/6), Kurumlar Vergisinden muaftırlar.

Ancak bu muafiyetin tanınabilmesi, vakiflara (veya eski vakıflara) ait müiesseselerin, yukarıda belirtilen maksat ve gayelerle işletildiklerinin, ilgili bakanların mütalâası alınmak suretiyle Maliye Bakanlığınca kabul edilmesinden sonra mümküindür (Kur. VK. $7 / 7)$.

7338 sayll Veraset ve Intikal Vergisi Kanununa göre, veraset tarikiyle veya ivazsız bir tarzda mal iktisap eden şahıslar Veraset ve Intikal Vergisi ödemekle mükelleftirler (m. 5). Bununla beraber, kanunun 3 üncü maddesinin (b) bentine göre, (a) bentinde «...sayılanlar dıșında kalan hükmî şahıslara - ki vakıf sayllmamıștırait olup umumun istifadesi için ilim, araștırma, kültüit, sanat, sthhat, eğitim, din, hayır, imar, spor $\mathrm{g}$ i b i maksatlarla kurulan teșekküller» Veraset ve Intikal Vergisinden muaftırlar.

Yukarıda sayılan gayelerin gerçekleştirilmesi için bir vakıf kurulabileceğine göre, tahsis olunan mallar iktisap eden vakıf, Veraset ve Intikal Vergisinden muaf demektir.6

13.7.1956 tarih ve 6802 sayılı Gider Vergileri Kanununda vakıflara ilișkin bir istisna hüikmü mevcuttur. Bu istisna, elektrik enerjisine dairdir. 10 uncu maddenin (a) bentine göre «... (eski) vakuflara ait —ki biz bu deyiși vakıflara da teşmil ederek madde hükmünü değerlendiriyoruz- hastane (sanatoryum, prevantoryum, dispan-

\footnotetext{
${ }^{6}$ Ayn Kanunun 4 üncï maddesine göre vergiden muaf tutulan vakuflarnn, vakıf senetlerinde belirtilen şartlar dahilinde ve gayelerine uygun olarak yaptıklan yardımlar, Veraset ve Intikal Vergisinden istisna edilmiştir (m. $4 / f$ ).
} 
ser dahil), düșkünleri koruma müesseseleri» gibi yerlerde ve ișlerde sarf edilen elektrik enerjisi gider vergisinden müstesnadır.

Bunun dıșında, aynı kanunda, doğrudan doğruya vakıflarla ilili bir istisna hükmü olmamakla beraber, gayeleri itibariyle ica. bında vakıfların da yararlanabilecekleri bir istisna hükmüne ișaret cimekte fayda vardır. Bu, m. 4/i/II'ye göre «Münhasıran eğitim ve ogretinde kullanlan alet, makina ve cihazlar»ı vergiden istisna k1. lan hükümdür.

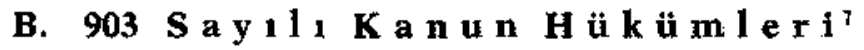

Bu Kanuna göre, vergi hukuku yönünden, vakıfları iki kategoriye ayırmak mümkündür: a) Bakanlar Kurulunca kendilerine vergi muafiyeti tanınan vakıflar, b) Diğer vakıflar.

\section{1) Bakanlar Kurulunca Kendilerine Vergi Muafiyeti Tanman Vakfflar :}

a) Genel Olarak:

Hukukumuzda, vakfın gayesinin münhasıran kamuya yararłı olmasın öngören bir hüküm mevcut değildir. Ancak 903 sayılı Kabuzun 2 ve 4 üncü maddeleri birlikte müitalâa edildikleri takdirde, "kamuya yararlt nitelikteki gayeler" için kurulacak vakıflarda, ${ }^{8}$ bir yandan vâkıfa, diğer yandan da vakıflara ve onlara yardımda bulunanlara bazı imtiyazlar tanınmış olduğu görüilüir.

710 Nisan 1971 tarihi itibariyle, bu kanun hükümlerine göre kurulmuş va. kıfların sayısı 129'dur. Bu Kanundan önce kurulmus vakıflardan 41'i de "merkezi sicile kayıt" için müracaatta bulunmuştur. Bu rakama «istihdam edilenlere ve işçilere yardım vakıfları" da dahildir (Bu bilgi Vakıf. lar Genel Müdürlüüg̈inden alınmıştır).

S Sanver, s. 10'da "Kanun, vergi muafiyeti tanıabilecek vakıflardan 'kamu hizmeti' deł̆il, 'bir hizmet' beklemektedir. Bu hizmet, genel, özel ve katma bütçede yer alan hizmetlerden olmalıdır. Bu bütçelerde yer alan hizmet. ler pek çeşitli olduğundan, vakıf adeta her hizmet için imkân dahilinde. dir. Böylece, çok geniş muafiyet görüșüne dayanan kanun 'kamuya ya. rarlı vakuf' deyimi yerine 'vergi muafiyetli vakuf' deyimini benimsemiștir. Artık, Türk hukukunda, özel vakıflar-kamuya yararlı vakıflar ayrımını vapmak çok gücçtïr. Ayrım, vergiye tabi vakıflar ve vergi muafiyetli vakıflar diye yapılabilir. Vergi teorisinin ve emsal hukuk sistemlerinin temel prensiplerine göre, vergi muafiyetli vakıflar kamuya yararlı veya özel gaye kolluyor olabilirler. Bu son halde, vergi imtiyazlı vakıflarla karşılașıyoruz» demektedir. 
Bu Kanunun 2 nci maddesi ile, MK. 453'e eklenen ikinci fikra hükmüne göre "Kamu yararına yapılan hibelerde ${ }^{9}$ ve gelirlerinin yansından fazlası kamu görevi niteliğindeki ișlerin yapımına bıra. kılarak kurulacak vakıflarda..." mahfuz hisse nispetleri daraltıl. mıștır.

Maddede geçen "kamu görevi niteliğindeki ișler" den ne anla șllması gerektiği ise, yine, 903 sayıl Kanununun 4 üncü maddesine göre tayin olunur. 4 üncü maddede, Bakanlar kurulunca, vakıflara hangi şartlarla vergi muafiyeti tanınacağına dair esas hüküm sevkedildikten sonra, 5 inci maddede vergi kanunlarına eklenecek yeni hïkümler ile değiștirilen hükümler sıralanmıș bulunmaktadır.

4 üncü maddeye göre, "Bakanlar Kurulunca, gelirlerinin en az \% 80'ini, nevi itibariyle genel, özel ve katma bütçeli idareler bütçeleri içinde yer alan bir hizmetin veya hizmetlerin ${ }^{10}$ yerine getirilmesini istihdaf etmek üzere tahsisan kurulacağ kabul edilen va. kiflara, tahsis edilen miktar için, vergi muafiyeti tanınabilir».

Sadece, 903 saylı Kanuna göre kurulmuş olan vakıflar değil, bu Kanundan önce kurulmuş bulunan vakıflar da, 4 üncü maddedeki sartlar haiz olduklan takdirde, vergi muafiyetinden yararlanabilirler. Çünkü, bu Kanunun geçici 4 üncü maddesinde, 4 Ekim 1926 tarihinden sonra kurulmuş bulunan vakıflar hakkında da, bun. dan böyle bu kanun hükümlerinin uygulanacağı belirtilmektedir."

Bu hükümler karşısında, vakıflar, vergi muafiyeti kanaliyle iki türlii esash avantajdan yararlanmaktadırlar : Bir kere bizzat vakfın

\footnotetext{
${ }^{9}$ Kanım koyucu, 18 Nisan 1924 tarih ve 1424 sayllı eski Icra ve Iflâs Kanu-

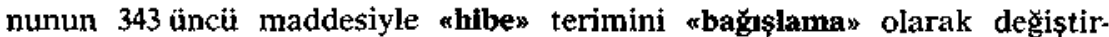
miş olduğu halde, bu değişikliğe kendisinin uymaması, kanunlar arasın. daki terim birliǧinin sağlanması bakımından üzücüdür.

10 Örneğin, g e n e l b ì t ç e ye dahil hizmetler, Millî Eğitim Bakanlığgl, Tanm Bakanlığı, Çalışma Bakanlığı, Turizm ve Tanıtma Bakanlığı, Săğık ve Sosyal Yardım Bakanlığl... gibi bakarilıklar tarafından gerçekleștiril. diğine göre, kamuya yararlı bir vakıf da, bu bakanlıkların kurulus kanus. larında gösterilen bir veya birden ziyade hizmetleri gerçekleștirmek için kurulmus olmaltdır.

Devlet Üretme Ciftlikleri Genel Müdürlüyüi, Orman Genel Müdürlüğü, Dev let Su Issleri gibi genel genel müdürlükler de $k$ a $t \mathbf{m}$ a bü $t c ̧$ e 1 i ida. relerdir.

Il özel idaresi, belediye ve köy ise $\ddot{o} z$ e 1 b ü $t$ ç e $1 \mathrm{i}$ idarelerdir.

r Bununla beraber, Maliye Bakanlığl, 903 sayll Kanundan önce kurulmuş bir vakfın, vergiden muaf kılınması talebi üzerine, tereddüde düşmüs ve Vakıflar Genel Müdü̈rlüğünün mütalâasını istemiștir. Maliye Bakanlığı Gelirler Gene! Müdürlüłü 22 Haziran 1968 tarih ve 22101-283/26161 savilt
} 
kendisi bir takım vergilerden muaftrr; ikinci olarak, vergiden muaf bir vakfa yaplian yardımlar da indirime tabidir. Konuyu, muafiyetin tanınması usulünden sonra, bu ayrıma paralel olarak iki bölümde ele alacağız.

\section{b) Murfivetin Tantnmast Usulï:}

4 üncï maddedeki şartları haiz bir vakfın, vergi muafiyetinden yararlanabilmesi için gerekli müracaat, ya vakfm kuruluş safhasında ya da kurulduktan sonra yapılabilir (Tüzük md. 37) :

a) Kuruluş safhasinda:

aa) Vâkılın sağı̆̆ında hüküm ifade edecek vakıflarda: Vakıf, vâkıfın sağllğı̆nda hükiüm ifade etmek üzere kuruluyorsa, Tüzüğün 37/II hükmü gereğince, vâkıf, kuracağı vakfın vergi muafiyetinden yararlanmasını istediği takdirde, dilekçesine, vakıf senedinin bir $t$ a s 1 a ğ 1 n 1 da ekleyerek Maliye Bakanlığına başvurur. Bu Bakanlık, gerekiyorsa, ilgili bakanliklarm, uygulamada Vakıflar Genel Müdürlüğününün de, düşüncelerini alarak, kendi görüșii ile birlikte, vakıf senedi taslağın, Bakanlar Kurulundan karar alınmak üzere, Başbakanlığa gönderir. Bakanlar Kurulunca, vakfa rgi muafiyeti tanınmasına karar verildiği takdirde, Maliye Ba-

yazısı ile "903 sayılı Kanunda tahsisen kurulacă̆ı Bakanlar Kurulunca kabul edilen vakıflara vergi muafiyeti tanınabileceği hüküm altına alınmıs olup kanunun meriyet tarihinden önce kurulmuş olan vakıflara vergi muafiyeti tanınacaşna dair bir hüküm bulunmamaktadır. Bu durumda kanunum meriyet tarihinden önce kurulmuș olan vakflara vergi muafiyeti tanımp tanınmiyacağı...» hususunda Vakıflar Genel Müdürlüğünün mütalâaSunı istemişıłix.

Vakrflar Genel Müdürlüğ̈i Hukuk Müşavirliği de, 11.10.1968 tarih ve 12-335 sayll yazısiyle "Mezkur kanunun 4 üncï maddesinde, tahsisen kurulacağı kabul edilen vakıflardan bahsedilmesine göre, muafiyetin, ancak bu kanunun mer'jyetinden sonra kurulacak vakıflara tanmabileceği düşünülebilirse de, aynı kanunun gç̧işi 4 üncü maddesinde de, Ekim 1926 tarihinden sonra kurułmus olan vakıflar hakkmda da bundan böyle bu kanun hü. kümlerinin taibik edileceği ifade edildiğinden; vergi muafiyeti ile ilgili hïkümlerin, bu vakıflara da tatbiki düşünülebilir. - tzah edilen sebeplerle, 903 sayılı Kanunun yürürlïğge girmesinden evvel kurulmuș olan vakıflara vergi muafiyeti tanınıp tanınmayacağı hakkında kesin bir hüküm mevcut olmadığından ve vergi mevzuu da daha ziyade Bakanlığmızın ihtisasına taallûk ettiộinden, içtihada müsait bulunan bu konuda müktezasının da Bakanlığınızca tayini gerektiği mütalâa olunmaktadır» cevabını vermiștir.

Vakfa, Bakanlar Kurulunca, vergi muafiyeti tanındığndan, sorun olum. lu şekilde çözünlenmiştir. 
kanlığı, $\quad$ t a s 1 a ğ 1 n bir ömeğini, bütün sahifelerini tasdik ederek, vakf 1 kuracak kişiye verir. Vakıf senedi bu taslağa uygun olarak noter tarafindan dïzenlendiği takdirde, vakıf vergi muafiyetinden yararlanır.

Tüzügüu 5/II hükmü gereğince,'2 resmî senetle kurulan vakıflarda, vâkıf veya onun ölümì halinde mirasçlarından birisi tescil talebinde bulunabilir. Vakıf senedinin diizenlenmesini takip eden üç ay içinde vâkıf veya ölümü halinde mirasçıları tarafından tescil talebinde bulunulmamıș veya vaikıf tüzel kişiliği haiz olupta bu süre içinde infisah etmişse, vakfın tescilini Vakıflar Genel Müdürrlüğù sağlar. ${ }^{13}$

Tüzüğüin 37/II hükmünde, yukardaki hükme paralel bir hükmün sevkedilmediği görülmektedir. Oysa Tüzük hükümleri arasında ahenki sağlamak bakımından, resmî senedin düzenlenmesinden itibaren üç ay içersinde tescil için müracaat edilmemişse, tescil talebi ve vakfun vergi muafiyetinden yararlanabilmesini saglama yet.

${ }^{12}$ Tüzüğün 5 inci maddesinin II nci fikrasının ilk cümlesi şöyledir: «Resmî senetle kurulan vakıflarda vakfeden, ölmesi halinde mirasçllardan birisi tarafından tescil talebinde bulưnabilirn. Görüldiuğï gibi bu cümlenin ifade tarzı bozuktur. Bu sebeple, ya cümlede geçen tarafindan kelimesinin çka. nlması, ya đa bulunabilir kelimesinin bulunabilir şeklinde düzeltilmesi gerekir.

13 Vakıflar Genel Müdürlïgüi, resmî senetle kurulan vakuflarda resmî senedi düzenleyen noterin, vasiyet yoluyla kurulan vakuflarda vasiyetnameyi açan sulh hâkiminin, resmî senet veya vasiyetnamenin bir örneğini yedi gün içersinde, kendisine göndermesiyle, durumdan haberdar olur (Tüziik md. $5 / 1)$.

Tüzüğün 5 inci maddesinin II nci fakrasının ikinci cümlesi şöyledir: «Va. kff senedinin düzenlenmesini takip eden üç ay içinde vakfeden... tarafın. dan tescil talebinde butunulmamıs... ise vakfın tescili hususundaki baș. vurma Vakıflar Genel Müdürlïgüi tarafindan yapılır».

Vakfflar Genel Müdürlüłüunce hazırlanan tüzük tasarısında (md. 3) böyle bir hüküm mevcut değildi. Adalet Bakanh̆ğnın 24 Șubat 1968 tarih ve 4468 saylı mütalaasımn I inci maddesindeki $*$... vakfeden, resmî senedin tanziminden sonra vakfı kurmaktan vazgeçemeyeceğinden, vakfedenin tescil için mahkemeye müracaat etmemesi... halinde vakfın durumunun ne olacağının açıklanmadığtna" işaret edildikten sonra ubu boşltuğun doldurulması için» yapılan teklif üzerine Vakıflar Genel Müdürlïuğince, tasan metnine alınmıştır. Kanımızca, vâkıf, kurmak istediği vakıftan, onun tes. ciline kadar cayabilmelidir (Bu konudaki tartışmalar için bkz. Ahmet Ișeri : Türk Medeni Kanununa Göre Vakıf 'Tesis', Ankara 1968, \& 8 I, s. 120 vd. Aynı kanat için aynca bkz. Hüseyin Hatemi : Onceki ve Bugünkü Türk Hukukunda Vakıf Kurma Muamelesi, Istanbul, 1969, s. 248 vd.; Ergun 0 z. sumay : Medenî Hukukumuzda Tưzel Kişiler, 2. Bası, Istanbul 1969, s. 175). 
kisinin vâkıfın mirasçılarına, vasiyeti tenfiz memuruna (Tüzügün 5/III maddesinden yararlanarak) ve Vakıflar Genel Müdürlüğüne tanınması gerekirdi kanısındayı.

bb) Vâkıfın ölümünden sonra hüküm ifade etmek üzere kurulacak vakıflarda: Vasiyetname ile veya miras mukavelesi içinde yer alan fakat yine de tek taraflı olna niteligini koruyan bir hükümle kurulan vakiflarda, Tüzüğün 37/III hükmü gereğince, vasiyetnameyi açan sulh hâkimi, vakfın vergi muafiyetinden yararla. רabileceği kanısına varırsa, vakıf senedinin bir örneğini göndere rck Maliye Bakanlığına başvurabilir. Sulh hâkiminin müracaat et. memesi ${ }^{14}$ halinde, vakfın yöneticileri de aynı yola başvurabilirler.

Maliye Bakanlığı, her iki halde de, yukarıda açıkladığımız usulii uygular.

Tüzïŭgun 5/III hükmü gereğince, vâkıfın ölümünden sonra hüküm ifade etmek üzere kurulacak vakıflarda, vâkıfın mirasçıları veya vasiyeti tenfiz memuru tayin ettiği kişi veya kișiler ${ }^{15}$ tescil talebinde bulunabilir. Vasiyetnamenin açılmasından itibaren üç ay içinde bu kişiler tarafından tescil talebinde bulunulmamıșa, vakfın tescilini Vakıflar Genel Müdürlüğü să̆lar. Oysa, Tüzüğün 37/III hükmüne göre, vakfn vergi muafiyetinden yararlanabilmesi için gerekli müracaatı, yukarıda da belirttiğimiz gibi, vasiyetnameyi açan sulh hâkimi veya onun yapmaması halinde, vakfın yöneticileri yapacaklardir.

Burada da tüzük hükümleri arasındaki ahenki sağlamak bakımından, vergi muafiyeti talebinin, tescili talebe yetkili olan vâkı. fan mirasçılarına, vasiyeti tenfiz memuru olan kiși veya kișiler ile Vakıflar Genel Müdürlüğüne tanınması (Tüzük md. 5/III) daha isabetli olurdu kanısindayı.

b) Vakfin k u r lmasindan son ra:

Tüziugüünün 37/IV hükmüne göre "vakfın kurulmasından sonra da vergi muafiyetinden faydalanmak için başvurulabilir». Görüldüğii gibi, maddede kimlerin talebe yetkili olduğu belirtilmemiștir.

\footnotetext{
${ }_{14}$ Tüzüigüü 37/III hükmünde geçen "... sulh hâkimi tarafindan müracaat edilmesi halinde de,...» ibaresindeki edilmesi kelimesi, metnin doğru an. laşılması bakımından, edilmemesi şeklinde olacaktır. Burada bir baskı ha. tas1 mevcuttur, zira 1.12.1969 tarih ve 1969/13 esas, 1969/21 karar sayılı Danıștay Birinci Dairesi tutanağında da bu husus belirttiğimiz șekildedir.

${ }^{5}$ Maddcde geçen a...vakfeden tarafundan mirası resmen idare etmekle gö. revlendirilmiş kişi...nden maksą, vasiyeti tenfiz. memturudur.
} 
Kanımızca, bu hususta vakfın yöneticilerinin ve Vakıflar Genel Mïdurluğunun yetkili olduğunun kabulï gerekir.

c) Bizatihi vakfa tantnms mali imtiyazlar:

903 sayılı Kanunun kendilerine vergi muafiyeti tanınmış olan vakıflar için getirmiș olduğu mali imtiyazlar şunlardır:

Bu vakıflar, Kurumlar Vergisinden muaf tutulmuşlardır. ${ }^{16}$

Bu vakıflara, kuruluṣ için veya kurulduktan sonra tahsis olu. nan mallar Veraset ve Intikal Vergisinden müstesna kılımmıșt.1. ${ }^{17}$

Aynı șekilde bu vakıflar, Emlâk Alım Vergisinden de muaf tu. 1.ulmuşlardır. ${ }^{18}$

Bu vakıfların kuruluş muamelelerinde düzenlenen her türlü kâğttlar Damga Resminden istisna edildiği to gibi, kurulus muameleleri ${ }^{20}$ ve bu vakıflara yapılacak bağıșmalarlar harçdan da muaf

Io 903 saylh Kanunun 5/A maddesi ile, 3.6.1949 tarihli ve 5422 sayll Kurum. lar Vergisi Kanununun 199 sayllı Kanun ile değișik 7 nci maddesine eklenen fıkra.

17903 sayll Kanunun 5/D maddesi ile, 8.6.1959 tarihli ve 7338 sayll Veraset ve Intikal Vergisi Kanununun 4 üncü maddesine eklenen (k) fikrassı.

Bu hükümde yeralan «kurulușu için veya» ibaresi, Cumhuriyet Senatosu Geçici Komisyonu tarafmdan «...vakıflarnn muafiyetten faydalanmaları $B$ a. kanlar Kurulu kararına bağlı olduğundan, kuruluş̧ için muafiyet temini mümkün olamıyacağı.... gerekçesiyle metinden çıkarılmışı) (Komisyonun 9.2.1966 tarihli E. 2/178, K. 2 sayli, 2 numaralı Raporuna bkz. Cumhuriyet Senatosu, Dön. 1, Top. 5, S. Sayısı: 709'a ek, sh. 3.)

Sonradan, Cumhuriyet Senatosu Genel Kurulundaki görüş̧meler surasinda, Konya Senatörü Muammer Obuz tarafmdan verilen ve Millet Meclisince kabul edilen metinde yeralan 5/D hükmünün aynen muhafazasın öngören önergenin kabulï üzerine, yeniden metni ithal edilmiştir (Cum. Sen. Tut. Der., Dön. 1, Top. 5, C. 34, 12.2 .1966 günlï 48 inci Birleșim, sh. 95, 97.)

18 903 saylı Kanunun 5/E maddesi ile, 18.2.1963 tarihli ve 198 sayılı Emlâk Alım Vergisi Kanununun 3 üncï maddesinin değiștirilen (b) fikrası.

19903 sayıl Kanunut 5/F maddesi ile, 11.7.1964 tarihli ve 488 sayli Damga Vergisi Kanununa bałłll 2 saylı tablonun $\mathrm{V}$ inci bölïmüne eklenen 19 uncu fikra.

Bu hüküm, Cumhuriyet Senatosu Geçici Komisyonunca metinden çlkarılmış, fakat, Senato Genel Kurulundaki görüssmeler esnasında verilen bir takririn kabulü üzerine tekrar metne ithal edilmiștir. Bu konuda dipnot 17 'deki gerekçe ve önergeye bkz.

${ }^{20}$ Bugün vakıfların kurulıș muameleleri harca tâbidir. 17.7.1964 tarihli ve 492 sayll Harçlar Kanununun noter harçları ile ilgili 2 sayılı tarifenin maktu harçlar bölïmünün 11 inci bentine göre «...ölüme baglı tasarruf se. 
kılınmıştır. ${ }^{21}$ Ancak, 4 üncü maddeye göre verilmiş olan Bakanlar Kurulu kararına rağmen, vakfin herhangi bir sebeple ${ }^{22}$ tescili mümkün olmaz ise, alınmayan Damga Vergisi ve harçlar, 6183 sayılı Amme Alacaklarmın Tahsil Usulü hakkındaki Kanuna göre tahsil olunacaktır. ${ }^{23}$

Diğer taraftan, bu vakıfların iktisabedecekleri gayrimenkulle. rin ve diğer aynî haklarmn tescilleri ve șerhi işlemleriyle, bu vakif. lusa ait işletmelerin ve bu işletmelerin sonradan iktisabedecekleri

net ve mukaveleleri... vakıf, aile vakıflari...» senetlerinin düzenlenmesi 25 lira maktu harca tabi kılınmıșt1. 29.7.1970 tarih ve 1318 sayılı Finansman Kanununun $106 \mathrm{ncr}$ maddesiyle, aynı tablonun aynı bentinde yapilan de. ğişiklikle, bu miktar 50 liraya çıkarılmıştır.

Bu durumda, vakıf, vâkıfın sağlığında (resmî senet) veya ölümünden sonra hüküm jfade etmek üzere (resmî vasiyetname veya miras mukavelesi içinde yer alan bir hüküm ile) kurulacak ise, bu işlemler harca tabidir; bu harcı vâkıf öđeyecektir.

21903 sayll Kanunun 5/G maddesi ile, 17.7.1964 tarihli ve 492 sayli Harclar Kanununun 38 inci maddesine eklenen fikra.

Bu hükmün de Cumburiyet Senatosu Geçici Komisyonu tarafından metin. den çıarıldığı anlaşılmaktadır. Fakat Raporda bu hususa her nedense temas edilmemistir. Bunun böyle olduğu Komisyonca kabul edilen metnin tetkikinden anlaşlabileceği gibi (Cumhuriyet Senatosu, Dön. 1, Top. 5, S. Sayısı: 709'a ek, sh. 10); Cumhuriyet Senatosu Genel Kurulundaki görüş. meler sırasında Konya Senatörü Muammer Obuz tarafindan verilen bir önergede de, bu madde hükmünün aynen muhafaza edilmesi istenilmiştir. Bu önergenin kabulü üzerine madde tekrar metne ithal edilmiştir (Cum. Sen. Tut. Der., Dön. 1, Top. 5, C. 34, 17.2.1966 günlï, 48 inci Birleșim, sh. 95, 97).

${ }^{22}$ Millet Meclisi Vakıflar Geçici Komisyonunun 18.4.1966 tarihli ve E. 2/250, K. 2 sayıll Raporunda, vakfın tescilinin "fiilî ve hukukî sebeplerle» miimkün olamayacağı belirtilmektedir (Milet Meclisi, Dön. 2, Top. 1, S. Sayısı: 99, sh. 4).

Örneğin, MK. 74/II gereğince "Kanuna, ahlâka ve âdaba veya millî menfaatlere aykırı olan veya siyasî düsünce veya belli bir ırk veya cemaat mensuplarmı desteklemek gayesi ile kurulmus olan vakıfların tesciline karar verilemez». Bu takdirde, vakfın kurulması için yapılan işlemlerin tabi ol. dukları Damga Vergisi ve harcların. Amme Alacaklarının Tahsil Usulï Hakkmdaki Kanuna dayamlarak tahsili cihetine gidilecek demektir.

23903 sayıl Kanunun 5/N hükmü.

Bu hïküm, teklifin, Cumhuriyet Senatosu Genel Kurulunda görüşülmesi strasında, Konya Senatörü Muammer Obuz'un bir önergesi üzerine, Senatoca kabul edilip, teklife eklenmiştir (Cum. Sen. Tut. Der., Dön 1, Top. 5, C. 34, 17.2.1966 günlï 48 inci Birleşim, sh. 95, 97).

Bu ilâve, Millet Meclisi Vakıflar Geçici Komisyonun 18.4.1966 tarihli ve E. 2/250 sayılı Raporunda da muvafik mütalâa edilmiştir (Millet Meclisi, Dön. 2, Top. 1, S. Sayısı: 99, sh. 3-4). 
gayrimenkullerin ve sair aynî hakların tescilleri ve şerhi gerektiren işlemleri ve bunların terkinleri de harcdan istisna edilmiştir. ${ }^{24}$

Kendilerine vergi muafiyeti tanınan vakıflara ait arazi ve arsalar, vakıf senedindeki cihete tahsis edilmek şartiyle, Arazi Vergisin. den müstesna kılınmıştır. ${ }^{25}$

Vakıf senedindeki cihete tahsis edilmek şartiyle, bu vakıflara ait binalar ile, ${ }^{26}$ ticaret kastı olmamak șartiyle, bu vakıflar tarafından kamu yararına vücuda getirilen su bentleri, su setleri, suların yükselmesine karşı manialar, kanallar, cetveller, bataklıkları kurulma veya kurak yerleri sulama tesisatı, Bina Vergisinden istisna edilmiștir. ${ }^{27}$

Bu vakıflara, konularna uygun olarak bağıș yolu ile gelen eşya ile; bu tip vakıfların hayrî mevzularına uygun bir işte kulan. mak şartiỳle, ithal edecekleri eşya, Bakanlar Kurulu karariyle Güm rük Vergisinden istisna edilebilir. ${ }^{28}$

29.7.1970 tarih ve 1319 sayılı Emlâk Vergisi Kanununun 4 üncü maddesinin (m) bentine göre, bu vakıflara ait binalar, "vakıf senedindeki cihete tahsis edilmek şartiyle» bu vergiden istisna edilmiş. tir.

d) Vakfa yardtmda bulunanlara tantnmıs imtiyazlar:

Safi kurum kazancından bu vakuflara sermayeye iştirak nispe. tinde ödenecek miktarlar Kurumlar Vergisinden müstesna kılınmıștir..$^{29}$

Bu vakıflara makbuz karşılı̆̆ında yapılan bağış ve yardımlar Kurumlar Vergisinden istisna edilmiştir. Ancak bu istisnadan yararlanabilmek için, bir takvim yılı içinde yapılan bağış ve yardımlar

24903 saylı Kanunun 5/H maddesi ile, 17.7.1964 tarihli ve 492 saylı Harclar Kanununun 59 uncu maddesinin (a) fıkrasının değiştirilıniş şekli.

2003 saylı Kanunun 5/I maddesi ile, 6.7.1931 tarihli ve 1833 sayll Arazi Vergisi Kanununun 2 nci maddesine eklenen (F) fikrast.

26903 sayılı Kanumun 5/J maddesi ile, 14.7.1931 tarihli ve 1837 sayılı Bina Vergisi Kanununun 3 üncü maddesinin 8 inci frkrasının değiştirilmiş \$̧ekli. 27903 sayll Kanunun 5/J maddesi ile, 14.7.1931 tarihli ve 1837 sayılı Bina Vergi Kanununun 3 üncii maddesinin 8 inci fikrasmın değiștirilmiș sekli. 28903 saylı Kanumun 5/M maddesi ile, 5383 sayll Gümrük Kanununun 17 nci maddesinin 2 nci fikrasının değiştirilmiş şekli.

29903 sayll Kanunun 5/B maddesi jle, 3.6.1949 tarihli ve 5422 saylh Kurum lar Vergisi Kanununun 199 sayılı Kanun ile değişik 8 inci maddesine ekle. nen 6 ncl fikra. 
toplamının o yıla ait kurum kazancının \% 5 'ini aşmaması şarttır. Bă̆ış ve yardımın nakden yapılmaması halinde \% 5 nispetinin nasıl hessplanacağı da belirtilmiştir. Şöyle ki : «... Bağışlanan veya yardımon konusunu teșkil eden mal veya hakkın maliyet bedeli ${ }^{30}$ veya inukayyet değeri, ${ }^{31}$ bu değer mevcut değilse Vergi Usul Kanunu hükümleri dairesinde takdir komisyonlarnnca ${ }^{32}$ tespit edilecek degerj esas almnr. ${ }^{33}$

Eu tip vakıflara, gelir vergisi mükellefleri tarafindan makbuz karşılığında yapılan bağış ve yardımlar, Gelir Vergisinden istisna edilmiştir. Ancak bu istisnadan yararlanabilmek için, mükellefin bir takvim yllı içinde yaptığı bağıș ve yardımlar toplamının o yıla ait beyan edeceği gelirinin \% 5’ini așmanaası şarttır. Bağıs ve yardımin nakden yapılmaması halinde bu nispetin nasıl hesap edileceği do bolirtilmiștir. ${ }^{34} \mathrm{Bu}$ ișlem, kurumların nakden yapmadıkları bağıș ve yardımlar hakkında, kanunun 5/C maddesi ile Kurumlar Vergisi Kanunı!nda yapılan değișiklikte belirtilen hesaplamanın aynıdır, Bu sebeple yukarıda bu konuda verdiğimiz malûmatı hatırlatmakla yetiniyoruz.

Türkiye'de istihsal veya imal edilerek müstahsilleri tarafından, Eakanlar Kurulunca vergi muafiyeti tanınan vakıflara, makbuz karșllı̆̆ında bedelsiz bağıș ve yardım şeklinde verilen maddeler İstih. s.l Vergisinden istisna edilmiștir. ${ }^{35}$

\section{2) Diłer Vakuflar :}

903 sayll Kanun, vergi muafiyeti șartlann (m. 4) haiz olmayan vakuflar hakkında, doğrudan doğruya değil, fakat dolaylı olarak.

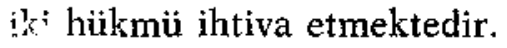

30 Vergi Usul Kanununa göre, «Maliyet bedeli, iktisadî bir kıymetin iktisap edilmesi veyahut değerinin artırılması münasebetiyle yapılan ödemelerle bunlara müteferri bilûmum giderlerin toplamını ifade eder» (m. 261/1, 262).

31 Vergì Usul Kanununa göre, "Mukayyet değer, bir iktisadî kıymetin muha sebe kayıtlarında gösterilen hesap değeridir" (m. 261/4, 265).

\$2 Takdir komisyonlar hakkında Vergi Usul Kanununun 72-76, konumuzla ilgili olarak bilhassa $74 / \mathrm{b}$ ve dolayisiyle 31 ve 30 uncu maddelerine bkz.

s3 903 sayılı Kanunun 5/C maddesi ile, 3.6.1949 tarihli ve 5422 sayll Kurum. lar Vergisi Kanununun 14 üncii maddesinin 199 sayılı Kanun ile değişik 6 uck madesinin değiştirilmis sekli.

- 903 sayıl Kanunun 5/L maddesi ile, 193 sayll Gelir Vergisi Kanununun 89 uncu maddesinin dậșstirilmiş 2 nci fukrası; ayrica Gelir Vergisi Kanuriu. md. 96/2-A/b'ye bkz.

$35 \$ 03$ sayul Kanumun 5/K maddesi ile, 13.7 .1965 tarihli 6802 sayll Gider Ver. gileri Kanununun 4 üncỉ maddesinin değiștirilmiş (E) fıkrası. 
Birincisi, kurumların, bu vakıflara makbuz karșılığında yapacakları bağıs ve yardımların Kurumlar Vergisinden istisna $\epsilon$ dilme. sine dairdir. Bu istisna hükmüriden yararlanabilmek için, kurumun bir takvim yılı içinde yaptığı bağıș ve yardımlar toplamının, o yıla ait kurum kazancının \% 2'sini ve yirmi bin lirayı aşmaması gerekir Aksi halde, kurum kazancmın \% 2 'sini ve her halde yirmi bin lirayı aşan kısım hasılattan indirilmez. Bağıs ve yardımın nakden yapılmaması halinde bu değerlendirme, 903 sayılı Kanunun 5/C maddesi ils, Kurumlar Vergisi Kanununda yapılan değişikliğe uygun olarak saplacaktır. ${ }^{36}$

Ikincisi, Gelir Vergisi mükelleflerinin, bu vakıflara makbuz kar. sllığında yaptıkları bağıs ve yardımlarm, yıllık beyanname ile bildi. recekleri gelirlerinden indirilmesi hakkındadır. Ancak bu hükümden yararlanabilmek için, mükellefin bir takvim yılı içinde yapmış oldu. ğ bağıs ve yardımlar toplamının, o yıla ait beyan edeceği gelirinin \% 5 'ini aşmaması gerekir. Aksi halde, bu nispeti așan kısım gelirden indirilmez. Bağışlama ve yardımın nakden yapılmaması halinde bu r.ispetin nasıl hesap edileceği de belirtilmiştir. ${ }^{37}$ Bu hesaplama, ku. rumların nakden yapmadıkları bağıș ve yardımlax hakkında, yukarıda verdiğimiz izahata uygun olarak cereyan edecektir.

Görülïuyor ki, her iki hüküm de, vergi muafiyeti șartların ha. iz olmayan vakıflara yapılacak yardımları teșvik edici niteliktedir.

903 sayılı Kanunun, vergi hukuku yönünden getirdiği hükümler, daha teklifin Millet Meclisine sevki ile birlikte tenkide uğramıștır. Aybay, ${ }^{38}$ Vergi bağışıklıkları sayesinde kurulacak vakfa ait

36 903 sayılı Kanunun 5/C maddesi ile, 3.6.1949 tarihli ve 5422 sayıl Kurum. lar Vergisi Kanununun 14 üncü maddesinin 199 sayılı Kanun ile değişik $6 \mathrm{ncl}$ fıkrasının değiştirilmiş birinci fıkrası.

3903 saylı Kanumun 5/L maddesi ile, 193 saylı Gelir Vergisi Kanununun 1963 tarihli ve 202 saynli Kanun ile değiştirilmiş 89 uncu maddesinin 2 nci flkrașının, dę̆łiștirilmiş șekli.

\$ Aydun Aybay : Vakıflara Dair Kanun Tasarısı, Cumhuriyet Gazetesi, 2.7. 1965 , s. 2. Yön, (27 Ağustos 1965, No. 126, s. 12) de aynı görüşü paylas. maktadır: «Görülecek kamu hizmetlerinin neler olduğunun tesbiti(ni) kıs. men bile olsa özel şalııllara bırakmanın, plan ve sosyal devlet anlayışı ile bałğaşamıyacă̆ı aşikàrdır... Ustelik vakfın gelirinin kamu hizmetlerine harcanmasını sağlayıcı kesin hüküumler de getirilmiş deł̧łldir. Vakfın gelirini kamu hizmetlerine tahsisle yetinip, bu parayı sermayeye eklemek mümkündür. Sermaye büyüdükçe de, gelirin yüzde 20'sini paylașma hakkına sahip bulunan mirasçıların hisseleri de artacaktır... Ustelik vakıf haline getirilen işletmeler, Kurumlar Vergisi de ödemiyecektir. Bu büyük vergi avantajı, rakip ișletmelerle mücadeleyi kolaylaștıracak ve kârlan önemli ölçiide artıracaktır..." denilmektedir. Ayrıca bkz. Kenan Bulutołơlu: Türk Vergi Sistemi, 2. bask1, Istanbul 1967, s. 171-172; Sanver, s. 7 vd. 
ișletmeler, aynı olacaklardır. Saklı paylarını gelirin \% 20 'si ile alacak mirasçılar için de bu bir avantajdır. Sonra, vergi ba ̌̆ıșıklığı veraset vergisini de kapsamaktadır. Devletin bu yoldan kaybedeceği pay da büyuiktür. Gerçi gelirin $\% 80^{\prime}$ i kamu hizmetine sarfedileceği için, bu kaybın önemli olmadı̆̆ı söylenebilir. Ne var ki, bütün vergi kayıpları gözönünde tutulursa, kamu yararna harcanacak gelir tahsisinin pek önemli olmayacağı sonucuna varılabilir. Üstelik, yapılacak kamu hizmetinin ne çeşit hizmet olacağı vakfı kuran tarafından tayin edileceği için burada devletin kamu hizmetleri ve harcamaları politikasına da bir müdahale kabul edilmiş olmaktadırn, demektedir.

Kanunun yürürlüğe girmesinden sonra, bu konudaki fikirler tam manasiyle ikiye bölünmüş bulunmaktadır. Bir görüș, vergi muafiyeti ile ilgili hükümleri olumlu karşılarken; diğer bir görüș, olumsuz bulmaktadır. Güngör ${ }^{30}$ "...Bakanlar Kurulunun bir vakfa vergi muafeyeti tanıması konusunda vereceği kararlar demokrasi ortaminda Parlâmentonun, basının ve ilgili çevrelerin dikkatlerine konu olacak, ayrıca kazaî murakabeye de tabi bulunacaktır. Bu nedenlerle demokratik düzenin çok cepheli denetleme fonksiyonu karşısında kanunun uygulaması ve vakıf müessesesinin işleyişi ile alâkalı olarak tereddütlere ve olumsuz düşüncelere kapilmamak yerinde olur kantsmdayız» demektedir. Bu görüșii Ervardar da ${ }^{40}$ paylașmakta. dir.

Buna karșılı Aybay, yukarnda işaret ettiğimiz fikirlerini, daha sonraki iki makalesinde ${ }^{41}$ işleyerek, 903 sayılı Kanunun, vakuflara tanıdığı vergi muafiyeti hükümlerini tenkit etmektedir.

$\mathrm{Bu}$ tenkitlerde hakl taraflar bulunmaktadur. Ancak, bu konuda kesin bir fikir ileri sürebilmek için, kanunun bir süre uygulanıșını beklemek, daha isabetli bir davranış olur kanısındayız.

${ }^{39}$ Burhan Giingör : Tesis, Vakıf ve 903 Sayl1 Kanun, Cumhuriyet Gazetesi, 8.9.1967, s. 2.

${ }^{40}$ Fehamettin Ervardar : Bazı Vakıflara Yeniden Kabul Edilen Vergi Mua. fiyetleri, Iktisat Gazetesi, 14.9.1967, s. 4, 7: "Yeni kanunla kabul olunan muafiyet ve istisnalarn, söz konusu vakiflarm, herhangi bir suiistimale düşmemelerini sağlayacak, ciddi ve müessir kontrol ve murakabeye tabi kılmaları kaydı ile, çok isabetli olduğı ve genis faydalara vesile olacağı kanaatindeyiz». Aynca bkz. Vakur Versan : Kanunda Yapılan Deł̧işiklik ve Illâvelerle Özel Kișiler de Kolaylıkla "Vakıf» Tesis Edebilecek, Yeni Gazete, 22.8.1967, sh. 2.

${ }^{41}$ Aybay, Vakıflarla İlgili Yeni Bir Kanun, sh. 2; Aybay, 903 Sayll Yasa Hakkında, sh. 2. Bu yazısında Aybay, Güngör'ün görüş̧lerini cevaplandırmaktadir. 


\section{III - VAKIFLARA, VERGILENDIRME ISTLEMLERİ SEBE. BİYLE VECİBELER YÜKLEYEN HÜKÜMLER}

Gelir Vergisi Kanunu 94'e göre, vakıflar (ve eski vakıflar) ${ }^{42}$ ile bunların iktisadî işletmeleri, hizmet erbabına ödedikleri iicretlerden ve diğer bir kısım ödemelerden Gelir Vergisi tevkifatı yapmakla yükümlüdürler. Burada, vakuflar ile bunların iktisadî ișletmeleri vergi sorumlusu olmaktadirlar (V.U.K. 8/II).

Vergi Usul Kanunu 172/I'in 4 üncü bentine göre, vakıflara (ve eski vakıflara) ait iktisadî işletmeler defter tutmağa mecbur olup, bu bakımdan tacirlerin tâbi olduklan hükümlere tâbi kılınmıșlar. dır (V.U.K. 172/II).

Ancak, Kurumlar Vergisinden muaf olan vakıflara (ve eski vakıflara) ait iktisadî ișletmeler (Kur. VK. 7/3), defter tutma mecburiyetinden istisna edilmișlerdir (V.U.K. 173/I bent 3/b).

27.7.1967 tarihli ve 930 saylı Tasarruf Bonolarn Ithracı hakkındaki Kanunun ${ }^{43} 4$ üncü maddesine göre, vakıflar (ve eski vakıflar) ${ }^{44}$ ile bunların iktisadî işletmeleri, aynı Kanunun 3 üncï maddesine göre tasarruf bonosu kesintisi yapmakla yükürnlüdürler.

Bu bölümde, vakıflara gerçek bir vergi yuikümüi değil, fakat vergi benzeri bir yüküm ${ }^{45}$ getirdiği için, MK. 78/III hükmüne de işaret etmek isteriz. Bu hükümde, 903 sayılı Kanundan önce veya sonra kurulmuș bulunan bütün vakıfların, Vakıflar Genel Müdürlügüine, safi gelirlerinin * $\% 5$ 'ini geçmemek üzere, teftiş ve denet-

42 Maddede geçen "tesis ve vakıf» terimleri, 903 sayılı Kanunun 3 üncü maddesi dikkate alınarak "vakıf" ve «eski vakıf" şeklinde düzeltilmiștir.

${ }^{43}$ Bu mahiyette bir hüküm, 223 sayılı Yatırımlar Finansman Fonu Teşkil ve Tasarruf Bonoları thracı hakkındaki Kanunun 4 üncï maddesinde de mevcut idi.

4" Maddede geçen, "tesisler", "vakıflar», "tesis ve vakıfların iktisadî ișletme. leri" terimleri, kanun koyucunun, kendi eseri olan 903 sayll Kanunun 3 üncü maddesi hükmüne, yine kendisinin uymadığını göstermektedir. Herhalde, kanun koyucunun maksadr, 903 sayll Kanundan önce kurulmuş olan «tesisler» ile, bu Kanuna göre kurulmuș veya kurulacak olan "vakıflar» belirtmek olamaz. Zira aynı müiesseseyi iki ayrn terimle ifade etmekle, yine çelişmeye düşülmüs olurdu. Bizce maksat yukarıda belirttiłimiz gibi, MK'dan önceki ve sonraki vakıfları belirtmektir. Isște burada, «MK'dan önceki vakıf veya eski vakıf» ve "MK'a göre vakıf veya vakıf» ayırımı yapmanm ne kadar zorunlu olduğu kendini açıkça göstermektedir.

45. Bu konuda bkz. Akif Erginay: Vergi Hukuku, Ankara, 1971, s. 4 ve 50.

46 Vakıflar Genel Müdürlïgünce hazırlanan tüzük tasarısının 19 uncu mad. desinin birinci frkrasında «safi gelir»in, Gelir Vergisi Kanunundaki esas- 
leme masraflarma kattlma payt ödeyecekleri ve bu nisbetin de tïzük ile saptanacağ belirtilmiștir.

Bu nisbet, Tüzükte \% 5 olarak tesbit edilmiş, ancak ödenecek katılma payını 200:000 lirayı da geçemeyeoeği belirtilmiştir (Tüzük md. $22 / \mathrm{I})^{47}$

lara göre hesap edileceği belirtilmişti.

Tüzük Tasarısı hakkında Ankara Üniversitesi Hukuk Fakültesi'nin müta. Jâası (Hazırlayanlar: Prof. Dr. Kemal Gürsoy, Prof. Dr. Jale Akipek, Prof. Dr. Halûk Tandogan) s. 3-5'te, safi gelirin bu șekilde hesaplanması «..tat. bikatta güçlitiklere yol açacak, hatta çoğu zaman vakıfların bu esaslara göre bir safi geliri bulunmayacaktır. Filhakika, ticarî işletmesi olmayan vakıfłarda bilânço kârı ortaya çıkmaz. Kaldı ki, ticarî işletmesi olanlar da dahil bütün vakıfların her çeşit gelirleri vakfın gayesinin gerçekleştirilmesi için karşılık teşkil ederler; bunlar üzerinde serbest tasarruf etmek imkânı yoktur. Halbuki, vergi sisteminde bahis konusu olan gelir, sahibinin üzerinde serbestçe tasarruf hakkı olan bir malî unsurdur.," denilmektedir (daha geniş bilgi için bkz. Işeri. Vakıf, s. 444 ve s. 155, dn. 45). Vakıflar Genel Müdüirlìgü, tüzük tasarısını inceleyen Danıştay Birinci Dairesi'ne sunduğu muhtırada (s. 21) "...safi gelir, mutlak bir deyimdir. Vakfın hernevi geliri bu deyimin içine girer. Meselâ mernur ve müstahdemlerinin emeklilik haklannı karşılamak ve onlara bazı sosyal yardımJarda bulunmak üzere bir șirket tarafından kurulmuş olan vakfa, gerek işveren ve gerekse memur ve müstahdemler tarafından ödenen aidat, o vakfın geliridir. Şayet tüzükte, denetleme payının vakfın safi geliri üzerinden alınacağtna dair bir hüküm konulursa, aidatlar da gelir saylacağndan, denetleme payının, vakfın tüm gelirleri üzerinden alınması iktiza eder. Halbuki denetleme payınn, Gelir Vergisi Kanunundaki esaslara göre hesap edilecek safi gelir ùzerinden alınacağı tasrih edilirse, aidatlar gelir mefhumuna dahil olmayacă̆ından, vakıf, aidatlar ïzerinden bir pay ödeneyecektir. Bu itibarla Tasarıdaki hüküm vakıflarmn nef'inedir" sek. linde görüșịinü açłklamıştır.

Maliye Bakanlığı, 10 Nisan 1968 tarih ve 22123.139/14627 sayılı mütalâasinda "...vakıf́lar, gelir ve kurumlar vergilerine tâbi olmadıkJarından, Vergi Usul Kanunlar!nın mükelleflere yüklediģi ödevleri yapmaya mecbur olmadıklan gibi, Gelir ve Kurumlar Vergisi Kanunlarına göre kazançlar1nı tespite de mecbur lutulamiyacaklanndan, katılma payına esas olacak safi kârm, Gelir ve vergi kanunfarmdaki esaslara göre tesbit olunan mali blânço kàrına dayanılarak besap edilmesi tatbikatta tereddüt ve karışık. lıklara scbebiyet vereceğinden, 19 uncu maddedeki, Gelir Vergisi Kanunundaki esasłara göre» ibaresinin maddeden çıkartılmasını teklif etmiştir (Muhtira, s. 5).

Danıstay 1. Dairesi (1.12.1969 T. ve E. 1969, K. 1969/21 sayll Tutanak, s. 8), Maliye Bakanlığının bu muitalâasına uyarak, Tasarının 19 uncu mad. desinin birinci fıkrasındaki "Gelir Vergisi Kanunundaki esaslara göre" ibaresini metinden çıkararak, hükmü Tüiziuğün 22 nci maddesindeki șekliyle yeniden düzenlemiştir.

47 Arkara Û́niversitesi Hukuk Fakültesi, Mütalâasında (İseri, Vakıf, s. 445 ve s. 156) "geliri az olan vakıflarm denetleme masraflannın geliri çok 
Öte yandan, yine Tüzüğün aynı maddesinin ikinci fıkrasında, istihdam edilenlere ve işçilere yardum vakıflarında, safi gelirin na. sıl hesap edilecę̆gi ayrica düzenlenmiștir. Şöyle $\mathbf{k i}$ : bu vakıflara istihdam edilenler ve ișçiler ile işveren müesseselerinin ödedikleri aidat ve katılma paylan, yıllık gayri safi gelirin hesabında nazara alımmayacak; fakat bunların ișletilmesinden elde edilen gelirler, safi gelire dahil edilecektir. ${ }^{48}$

Vakfın yönetim organ, her yıla ait teftiş ve denetleme masraf. larına katılma payını, mart ayı sonuna kadar, Vakıflar Genel Müdürlüğüne ödemckle yükümlüdür (Tüzük mid. 22/III). Bu yüküme aykırı hereket eden vakıf yöneticilerinin (Tüzüik md. 23/I bent $\mathrm{I} / \mathrm{h}$ ), işten uzaklaştırılmaları konusunu aşağıda inceleyeceğiz.

\section{IV - MUAFIYET \$ARTLARINA, MÜKELLEFIYET VE SO- RUMLULUĞA AYKIRI HAREKET EDILMESINNIN VE KATILMA PAYININ GEç ÖDENMESİNIN MỦEYYİDE. LERİ}

\section{A. Vergi Muafiyetísartlarina Aykiri Hareket Edilmesi:}

Vergi muafiyeti șartlarına aykırı hareket eden vakıf hakkında nassıl bir işlem yapılacağı, Kanun ve Tüzükte belirtilmemiş, sadece Tüzükte vakıf yöneticilerinin, vakfın gelirlerini vakıf senedinde yazılı şartlara aykırı olarak sarf etmeleri halinde (Tüzük 23/I bent I/c), yöneticilerin işten uzaklaştırılacakları öngörülmüştür.49

olan vakıflara yüklenmesine bir sınır» konulması amacıyla, bir vakfun yalnız başına ödeyeceği katılma payını 25.000 lirayı geçemeyeceğini önermiş, fakat Profesör Jale Akipek, bu sınırJandırmaya muhalif kalmıștı (İseri, Vakıf, s. 449).

Vakıflar Genel Müdürlizğü de, «katılma payının 25.000 lirayı geçemeyece. ği yolundaki hükmün hiçbir mesnedi” olmadığmn ileri sürrmüștï (Muhtura, s. 22).

Sonradan, Danıştay 1. Dairesi (Yukarıda dn. 45'te anılan Tutanak, s. 8). Ankara Hukuk Fakültesi Mütalâasında 25.000 lira önerilen sınırı, 200.000 liraya çıkarmıştır.

48 Bu hüküm, Danıştay 1. Dairesi tarafından (yukarıda dn. 46'da anılan Tutanak, s. 8) «istihdam edilenlere ve işçilere yardın vakıflarının kurulus gayeleri gözönünde tutularak» konulmuştur.

49 Vakıflar Genel Müdürlüğunün hazırladığı tasarıda, teftiş ve denetleme masraflarım zamanında ödemeyen vakıf yöneticilerinin işten uzaklaştırilmasım öngören bir hüküm yoktu. Bunun yerine, Tasarınn 19 uncu maddesinin III üncü fıkrasında «Müddetinde ödenmeyen paylar o vakıftan tahsil edilmekle beraber, tahsil tarihine kadar geçen mïddet için, 
Bilindiği gibi, vakıflar, Vakıflar Genel Müdürlüğünün teftișine tabidir (MK. 78/I, Tüzük 19/I). Bu Genel Müdürlük bir vakfın durumunu ya müfettişleri aracılı̆̆ı ile yaptırdığı teftiș sonunda (Tü. zük 19/II) ya da vakfın yönetim organının her yl kendisine vermekle yükümlü olduğu bilgiler sonunda öğrenmiș olur.

Vakıflar Genel Müdürliuğu, her vakfı en az iki yllda bir defa teftiș ettirmekle yükümlüdür (Tüzük 20/I). «Her teftiște, vakfm bir önceki teftişinden itibaren geçen bütün işlem ve hesaplan in. calenerek, vakıf senedindeki hükümlerin yerine getirilip getirilmediği, vakfın mallarmın gayeye uygun şekilde idare edilip edilmediği ve vakfın gelirlerinin gayeye uygun olarak sarf olunup olun. madtı̆̆t araștırılır» (Tüzük 20/III, MK. 78/II). ${ }^{50}$

Teftiş sonunda verilen raporlar, Vakıflar Genel Müdürlüğince incelenir (Tüzük 21). Raporda, vakıf yöneticilerinin ișten uzaklaştırılmalarını gerektiren bir sebep, örneğin konumuzla ilgili olarak, vakfın gelirlerinin gayeye uygun olarak sarf olunmadığ 1 tespit edilmişse, derhal yetkili asliye mahkemesine, yazıl o olarak başurula. rak, yöneticilerin ișten uzaklaştırılmaları istenir (Tüzük 21/a, 23/I bent I/c, 23/II, MK. 79/II c. 1). Mahkeme duruşma yaparak, yöneticileri ișten uzaklaştırabilir MK. 79/II c. 1, Tüzük 23/II). Yetkili Asliye Mahkemesi, vakfın merkezinin bulunduğu yer Asliye Mahkemesidir (HUMK. 9/I). Iș̦ten uzaklaştırılan vakıf yöneticileri, bir daha yönetici olarak seçilemezler (Tüzük 24/II).

Diğer taraftan, vakfın yönetim organı, her takvim y1lı başında malî durumunun bir bilânçosunu yapmakla ve uygun mahallî vasıtalarla ilân veya neşretmekle yükümlüdür. Bilânçonun bir örneği de, merkezi sicildeki (MK. 74/I, Tüzük 11) özel hanesine ${ }^{\text {sl }}$ özet șeklinde kaydolunmak üzere, Vakıflar Genel Müdürlügüne gönderilir (Tüzük 29, MK. 81/II).

geçikmeye sebebiyet veren vakıf idarecilerinden ayrıca ylllk yüzde on faiz tahsil edilir» hükmüi mevcuttu. Bu hüküm sonradan Danıștay Birinci Dairesi tarafından metinden çıkarılmıs ve yerine yukarıdaki hüiüm komulmuştur (Danıștay 1. Dairesi, yukanda dn. 45 anılan Tutanak, s. 8).

so İșletmelere sahip olan vakıfların nasıl teftiș edilecełgi konusunda bkz. Tïzijk 20/IV.

51 Tüizìk gereğince merkezî sicil defterinde her vakıf için bir sahife açlır. Bu sahifedeki özel sütunlara nelerin yazılacağı ayn ayrı sayılmak suretiyle belirtildiği halde (Tüzük 12/1), bilânço özetine yer verilmemiștir. Vakıflar Genel Müdürlügüunce hazmrlanan merkezî sicil defterinde de bu husus gözönünde tutulmadığından, bu kaydın nasıl yapılacağı anlaşılama. maktadrr. 
Vakıflar Genel Müdürlüğü, bilânçonun tetkiki sonunda, vakfın gelirlerini, kendisine tanman vergi muafiyeti şartlarına (903 sayılı Kanun 4, Tüzük 37/I) uygun olarak sarf etmediğini tesbit ettiğinde, ya durumu bir kere daha vakıf nezdinde müfettişleri aracılı̆̆ı ile tetkik ettirir ve bunun sonucuna göre hareket eder veya doğrudan doğruya bilânçodaki bilgilerle yetinerek, vakuf yöneticilerinin işten uzaklaștırılması yoluna başvurur.

Kanımızca, bunun yanmda, Vakıflar Genel Müdürlüğgi, durumu vakfın merkezinin bulunduğu yer vergi dairesine de bildirmelidir. Vakıf bilânçosunu, mahallî vasıtalarla ilân veya neşrettiğine göre, bu duruma, vergi dairesi de bizzat muttali olabilir. Her iki halde de, vakfın vergi muafiyeti şartlamm kaybettiğini tesbit için Bakanlar Kurulu karanna lïzum yoktur.

Böylece, vakıf muaflıktan mükellefiyete geçtiği için hakkında duruma göre, Vergi Usul Kanununda öngörülen suçlarla ilgili hükümler uygulanır (V.U.K. 344 vd). Ełger vakıf, muafiyet șartlarına uymadığından dolayı durumu daha önce vergi dairesine bildirmiş. se, hakkında Vergi Usul Kanunundaki pişmanltk hïkümleri (V.U.K. 371) uygulanır. Her iki halde de vergi ve cezalar, aşağıda belirteceğimiz üzere vakfın malvarlığından tahsil olunur.

Muaflıktan mükellefiyete geçen bir vakfın, tekrar muafiyetten yararlanabilmesi için, yukarıda muafiyetin tanınması konusunda açıkladığımız şartlar ve usulle, yeniden Bakanlar Kurulunun kararinı istihsal etmesi gerekir.

\section{B. Teftis ve Denetleme Mastaflarina Kat $1 \mathrm{lma}$ Pay 1 n $1 \mathrm{n}$ ödenmemes i :}

Yukanda, vakuf yönetim kurulunun her ylla ait teftiş ve denetleme masraflarına katılma payın, mart ayı sonuna kadar, Va. kıflar Genel Müdürlügüne ödemekle yükümlü (Tüzük 22/III) olduğunu belirtmiștik. Bu yüküme aykırı hareket eden vakıf yöneticileri, vakfın gelirlerini vakıf senedinde yazılı șartlara aykırı olarak sarf etmeleri halinde olduğ̆ gibi, yukarıda açıkladığımız usulle, işten uzaklaştırılabilirler (Tüzük $23 / \mathrm{I}$ bent $\mathrm{I} / \mathrm{h}, 23 / \mathrm{II}$ ) ve bir daha yönetici seçilemezler (Tüzük 24/II). ${ }^{52}$

${ }_{52}$ Gerek vergi muafiyeti șartlarına aykın hareket edilmesi gerekse teftiş ve denetleme masraflanna katılma payınn süresinde ödenmemesi halinde, mahkemece ișten uzaklaștırılan yöneticilerin yerine vakıf senedine göre yenileri seçilir. Vakıf senedinde bu konuda bir hüküm yoksa Vakıflar Genel Müdürlügüünün yazzlı düșüncesi alınmak suretiyle vakıf yöneticileri mahkemece seçilir (Tüzük 24/I, MK. 79/II c. 1). 
C. Mükellefiyet ve Sorumlulü̆a Aykir H areket Edilmesi:

V.U.K. 10 gereğince, vakıfların (ve eski vakıflarm) mükellef ve sorumlu olarak yüklendikleri vecibeleri kanunî temsilcileri ifa eder. Vecibelerin yerine getirilmemesi halinde, tahsil edilemeyen alacak için, önce vakfin malvarlı̆̆na el konur, buradan tahsil edilemeyen kısım için de, vecibelerini kasıt veya ihmal ile yerine getirmeyen ka. nunî temsilcilerin malvarlığına müracaat edilir. Bu suretle dereceli bir sorumluluk esası kabul edilmiştir. Vergi cezaları bakımından da aynı esaslar uygulanir (V.U.K. 333/II).

Vakıf yöneticileri kendi malvarlıklannndan ödedikleri vergi “ c.zalar için vakfa rücu edebilirler (V.U.K. 10/III, 333/II). 